\title{
ポリ塩化ビフェニル分解キットの改良とイオンクロマト グラフィーによる絶縁油中ポリ塩化ビフェニルの簡易定量
}

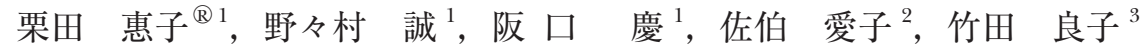

\section{Simple Method of PCB Determination in Transformer Oil by Improving PCB Decomposition Kit and Ion Chromatography of Chloride}

\author{
Keiko Kurita $^{1}$, Makoto Nonomura ${ }^{1}$, Yasusi SAkaguchi ${ }^{1}$, Aiko SAIKI $^{2}$ and Ryoko Takeda ${ }^{3}$ \\ ${ }^{1}$ Tokyo Metropolitan Industrial Technology Research Institute, 3-13-10, Nishigaoka, Kita-ku, Tokyo 115 - 8586 \\ ${ }^{2}$ Sibata Scientific Technology Ltd., 3-1 - 25, Ikenohata, Taito-ku, Tokyo 110 - 8701 \\ ${ }^{3}$ Bayer Medical Ltd., 1-6-5, Marunouchi, Chiyoda-ku, Tokyo 100-8263
}

(Received 14 April 2005, Accepted 21 July 2005)

\begin{abstract}
A PCB decomposition kit that is now available for measuring the amount of PCB in transformer oil by using a chloride ion selective electrode (ISE) has been improved to quantify 0.5 $\mathrm{mg} / \mathrm{kg}$ or less of PCB by using ion chromatography (IC). The minimum limit of determination by the current ISE with the original kit is $5 \mathrm{mg} / \mathrm{kg}$, whereas the new disposition standard of PCB in transformer oil is $0.5 \mathrm{mg} / \mathrm{kg}$ in Japan. The basic procedure of this kit is as follows; a sample of oil containing PCB is decomposed to chlorides $\left(\mathrm{Cl}^{-}\right)$by stabilized $\mathrm{Na}$ and the solvent in a kit. The $\mathrm{Cl}^{-}$are extracted in water and measured with IC. By this method, the quality of the chromatograms is not good enough for reliable high-resolution analysis. This is caused by the large amount of $\mathrm{NaOH}$ which is caused by $\mathrm{Na}$. The removal of this $\mathrm{Na}^{+}$in samples has been studied using the $\mathrm{H}^{+}$-form cation exchange resin, and it is found that $1 \mathrm{~g}$ of cation exchange resin is sufficient to remove the $\mathrm{Na}^{+}$in the improved PCB decomposition kit. The amounts of stabilized $\mathrm{Na}$ and the solvent have also been decreased to half the amount of the original kit, which results in no change in the recovery of $\mathrm{Cl}^{-}$and a better chromatogram. The analyzed data of real transformer oil samples containing PCB by IC and by ISE are in good agreement, but there are some differences in the data of $\mathrm{Cl}^{-}$lower than $5 \mathrm{mg} / \mathrm{kg}$. This new method was proved to be very useful for screening tests of $0.5 \mathrm{mg} / \mathrm{kg}$ of PCB in transformer oil.
\end{abstract}

Keywords : PCB in transformer oil; decomposition kit; ion chromatography; screening test; chloride ion; cation exchange resin.

\section{1 緒 言}

ポリ塩化ビフェニル（PCB）は電気的絶縁性の性質から 主としてコンデンサーやトランスの絶縁油や熱媒体の潤滑 油として使用されてきた。しかし，1968年のカネミ油症 事件によりその毒性が社会問題化し，1973 年には「化学

\footnotetext{
東京都立産業技術研究所：115-8586 東京都北区西が丘 3$13-10$

柴田科学株式会社：110-8701 東京都台東区池之端 3-1-25

3 バイエルメディカル株式会社：110-8263 東京都千代田区丸の 内 1-6-5
}

物質の審査及び製造等の規制に関する法律 (化審法)」が 制定, 施行され, PCB の生産, 輸入及び新規使用が禁止 された。また，1998 年には廃棄物処理法の特別管理産業 廃棄物でなくなる基準 (卒業判定基準) が改訂され, 廃油 中の $\mathrm{PCB}$ は $0.5 \mathrm{mg} / \mathrm{kg}$ という值が設定された。世界的に 見ると, この值は $50 \mathrm{mg} / \mathrm{kg}$ が普通であり, 最も厳しいも のでも $2 \mathrm{mg} / \mathrm{kg}$ で1)これらを比較すると日本の值はかなり 厳しいと言える. 2001 年には PCB 廃棄物適正処理推進特 別措置法が制定され，2016 年 7 月 15 日までに現在全国で 保管されているすべての絶縁油を処理することが求められ 

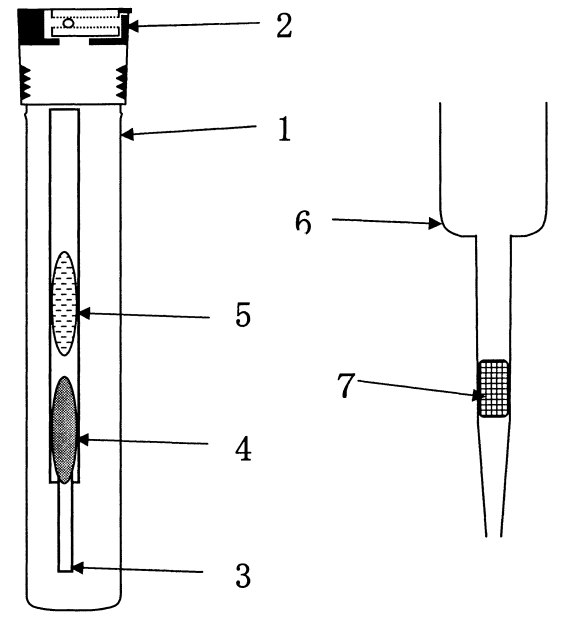

Fig. 1 PCB decomposition kit (L2000DX: DEXSIL) 1: Decomposition plastic tube, 2: Cap with a nozzle for an extract, 3: Stick for maintaining cartridges of reagents, 4: Cartridge of solvent (diethylene glycol dimethyl ether \& naphthalene), 5: Cartridge of metallic sodium, 6: Filter kit, 7: Filter

ている.

従来から廃油中の PCB の測定は主としてガスクロマト グラフ質量分析法あるいはガスクロマトグラフ法 ${ }^{2}$ で行わ れているが, 前処理が煩雑で時間がかかり費用も高いこと から，スクリーニングできる簡便な方法の開発が望まれて いる. 一般的に工場排水や底質等の PCB 分析では低級脂 肪酸や有機塩素系化合物を大量に含んでいるためこれらを 除去する前処理が必要である. しかし, 絶縁油は密閉系で 使用されるので，これらの混入はほとんど無く，また無機 塩化物や不純物の含有も少ないと考えられるので, 煩雑な 前処理を簡略化し, 不必要な操作を省くことにより, 操作 時間が短縮されるだけでなく分析精度の向上も期待でき る.

米国で現在使用されている PCB の分解キット（米国デ クシル製 L2000DX） は溶媒（ジグリムとナフタレン）と 金属ナトリウムにより絶縁油中の有機塩素化合物を塩化物 イオン $\left(\mathrm{Cl}^{-}\right)$に分解した後, 硝酸塩溶液に抽出してから 塩化物イオン電極（ISE）で定量するものであり米国環境 保護庁（EPA）で認定されている3). しかし，この方法で の定量下限值は PCB として $5 \mathrm{mg} / \mathrm{kg}$ であり, 日本の卒業 判定基準 PCB $0.5 \mathrm{mg} / \mathrm{kg}$ を定量できない.

本研究では絶縁油中の $0.5 \mathrm{mg} / \mathrm{kg}$ の $\mathrm{PCB}$ を定量するた めに, ISE の場合と同様に絶縁油中の PCB を溶媒と金属 ナトリウムで $\mathrm{Cl}^{-}$に分解し, 純水に抽出した後, 水素イオ ン型の陽イオン交換樹脂を加えて中性とし, イオンクロマ トグラフ (IC) 法で測定する最適条件を検討し, 実試料 を分析した結果を報告する。

\section{2 実験方法}

\section{$2 \cdot 1$ 装置及び器具}

$\mathbf{2} \cdot \mathbf{1} \cdot \mathbf{1}$ 装置イオンクロマトグラフ装置はダイオネ クス製の DX-500を使用した。

陰イオン分析の条件は, 分離カラムにダイオネクス製 IonPac AG12A/AS12A を, 溶離液に $2.7 \mathrm{mM}$ 炭酸ナトリウ ムと $0.3 \mathrm{mM}$ 炭酸水素ナトリウムの混合溶液を用い, 1.3 $\mathrm{ml} / \mathrm{min}$ で流し，アイソクラティック溶離法で行った。試 料注入量は $25 \mu \mathrm{l}$, カラム温度は $35^{\circ} \mathrm{C}$, サプレッサーは電 気透析型の ASRS-II を用い, 溶離液の廃液を使用したりサ イクルモード $(50 \mathrm{~mA})$ で行った. 検出器は電気伝導度検 出器を用いた.

陽イオン分析の条件は, 分離カラムにダイオネクス製 IonPac CG12A/CS12A を用い, 溶離液として $18 \mathrm{mM}$ メ夕 ンスルホン酸溶液を $1.0 \mathrm{ml} / \mathrm{min}$ で流し, アイソクラティ ック溶離法で行った。試料注入量は $25 \mu \mathrm{l}$, カラム温度は $35^{\circ} \mathrm{C}$, サプレッサーは電気透析型の CSRS-II を用い, 溶離 液の廃液を使用したリサイクルモード（50 mA）で行った. 検出器は電気伝導度検出器を用いた。

有機酸の分析は, 分離カラムに昭和電工製 ShodexIC SI90G/SI-50 4E を用い, 溶離液に $3.2 \mathrm{mM}$ 炭酸ナトリウムと $1 \mathrm{mM}$ 炭酸水素ナトリウムの混合溶液を $0.8 \mathrm{ml} / \mathrm{min}$ で流 し, アイソクラティック溶離法で行った。試料注入量は $25 \mu \mathrm{l}$, カラム温度は $35^{\circ} \mathrm{C}$, サプレッサーは電気透析型の ASRS-II を用い，溶離液の廃液を使用したリサイクルモー ド（50 mA）で行った。検出器は電気伝導度検出器を用い た.

2・1・2 PCB 分解用キット 市販されている $\mathrm{PCB}$ 分 解キット（デクシル製 L2000DX）の構成を Fig. 1 に示す. 分解管の中に分解溶媒 $\{$ ジエチレングリコールジメチルエ ーテル (ジグリム) とナフタレン\}, 金属ナトリウムをそ

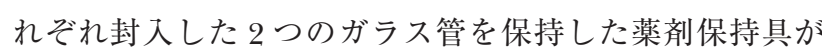
入っている。分解管と薬剤保持具は軟質プラスチック製で 外側から指で簡単に押しつぶすことができ，薬剤保持具に 保持された薬剤のガラス管を容易に割ることができる。キ ヤップは分解管にねじ达むもので開閉式の液の取り出し口 が付いている。また抽出液を沪過するためのフィルターが 付属している.

\section{$2 \cdot 2$ 試薬及び PCB 試料}

水はミリポア製純水装置 milli-Q SP で調製した超純水を 使用した。

イオンクロマトグラフ分析用標準試薬は, 関東化学製陰 イオン混合標準液 $\mathrm{IV}\left(\mathrm{F}^{-}, \mathrm{Cl}^{-}, \mathrm{NO}_{2}{ }^{-}, \mathrm{Br}^{-}, \mathrm{NO}_{3}{ }^{-}\right.$, $\mathrm{PO}_{4}{ }^{3-}, \mathrm{SO}_{4}{ }^{2-}$ ) 及び関東化学製陽イオン混合標準液 II $\left(\mathrm{Li}^{+}, \mathrm{Na}^{+}, \mathrm{NH}_{4}{ }^{+}, \mathrm{K}^{+}, \mathrm{Ca}^{2+}, \mathrm{Mg}^{2+}\right)$ を適宜希釈して調 
製した。有機酸の分析に際してはギ酸ナトリウム $0.378 \mathrm{~g}$ と酢酸ナトリウム $0.348 \mathrm{~g}$ を水で $250 \mathrm{ml}$ としてギ酸及び 酢酸の $1000 \mathrm{mg} / 1$ の標準液を調製し，これを適宜希釈し た液を装置の校正に用いた。

陽イオン交換樹脂は，オルガノ製水素イオン型陽イオン 交換樹脂アンバーライトIR124HAGを水で洗浄し, 沪紙 で挟んで水を切り，必要量をひょう量して用いた。

絶縁油はPCB を含まないトランスフォーマーオイル （出光 3XBP0030X4）をブランク試料及び標準試薬の希釈 用として用いた。 PCB の代替品として関東化学製の 1,2,4トリクロロベンゼン（TCB）を用いた。重量希釈で 0.2 , $0.5,1.0,2.0,3.0,5.0,20.0,50.0 \mathrm{mg} / \mathrm{kg}$ となるように 調製し, TCB 標準液とした。 PCBの標準試料としては KC600（鐘淵化学製 PCB カネクロール 600）を用い，同 様に $0.5,1.0,2.0 \mathrm{mg} / \mathrm{kg}$ となるように調製し, PCB 標準 液とした。

PCB 含有の実試料として, 低濃度 PCB 污染対策検討委 員会測定法 WG で実試料の分析評価のために産業廃棄物 処理事業振興財団より配布された試料 20 検体を用いた。

\section{$2 \cdot 3$ 定量操作}

\section{$2 \cdot 3 \cdot 1$ 絶縁油中 PCB の分解と定量法 試料（オイ}

ル） $5 \mathrm{~g}$ を Fig. 1 に示す分解管に入れ, 薬剤保持具に保持 されている $\mathrm{PCB}$ 分解溶媒のガラス管を割り, 10 秒間振り 混ぜる。次に金属ナトリウムのガラス管を割り 1 分間振 り混ぜ, 試料オイル中の $\mathrm{PCB}$ (あるいは TCB）を分解す る. 水 $5 \mathrm{ml}$ を加え, 1 分間振り混ぜ, 分解により生成し た塩化物イオンを水に抽出する. 陽イオン交換樹脂アンバ ーライトIR124HAG を一定量添加し 1 分間振り混ぜ，抽 出液のナトリウムイオン $\left(\mathrm{Na}^{+}\right)$を水素イオン $\left(\mathrm{H}^{+}\right)$と 交換する. 分解管を 10 分間倒置し, 抽出液と油分を分離 する. キャップの取り出し口を開け, 抽出液を押し出し, Fig. 1 に示すキットに付属したフィルター（ポリエステル 製）を通して別容器に取る。この沪液中の $\mathrm{Cl}^{-}$をイオンク ロマトグラフで分析し, 絶縁油中の PCB 濃度を求めた. $\mathrm{Cl}^{-}$濃度から PCB 濃度への換算を行うためには PCB の種 類を特定する必要がある。例えば KC600の場合, PCB1 分子中の $\mathrm{Cl}^{-}$の含有率は $60 \% \mathrm{w} / \mathrm{w}$ であるから得られた $\mathrm{Cl}^{-}$濃度を回収率 0.84 で割り, これを本来得られるべき $\mathrm{Cl}^{-}$濃度とし, これを 0.6 で割ることにより KC600 濃度に 換算できる。回収率についてはすべての PCBに 0.84 を用 いる。各種の $\mathrm{PCB} の \mathrm{Cl}^{-}$含有率は $\mathrm{KC} 300, \mathrm{KC} 400$, KC500，KC600，KC1000 についてそれぞれ 42，48，54， 60，92\%である.この論文中では PCB 濃度への換算は行 わず，結果を得られたそのままの $\mathrm{Cl}^{-}$濃度で表示してい る.

$$
\text { 2・3・2 PCB 定量下限値の測定 PCB の一種である }
$$

KC600 をトランスフォーマーオイルで希釈し 0.5，1.0， $2.0 \mathrm{mg} / \mathrm{kg}$ に調製した標準液を用いて各濃度で 6 回の分解 と定量を $2 \cdot 3 \cdot 1$ の操作手順に従って行い, 各濃度での相 対標準偏差を算出し，相対標準偏差 10\% の濃度を定量下 限值とした。

\section{3 結果と考察}

\section{$3 \cdot 1$ PCB 分解キットを用いる絶縁油中 PCB の分解法 \\ の検討}

炭化水素は通常金属ナトリウムとは反応しないが，ナフ タレンやビフェニルなどの芳香族炭化水素とはジグリムや テトラヒドロフラン等の溶媒中で容易に反応する ${ }^{4)}$. ナフ タレン $\left(\mathrm{C}_{10} \mathrm{H}_{8}\right)$ の場合は,

$$
\mathrm{C}_{10} \mathrm{H}_{8}+\mathrm{Na} \longrightarrow\left[\mathrm{C}_{10} \mathrm{H}_{8}\right]^{-} \mathrm{Na}^{+}
$$

となり，生成物はナフタレンナトリウムという極めて強 い還元性の物質 ${ }^{5)}$ となり，ナトリウムを直に使うよりもス ムーズに還元反応が進行する．ビフェニルナトリウムでも 同様の効果が報告されている ${ }^{6)}$. 本研究では ISE 用に用い られているジグリムとナフタレンの分解溶媒と金属ナトリ ウムからなる分解キット (L2000DX) 中で生成されたナ フタレンナトリウムで絶縁油中の PCB を分解し, 生成し た $\mathrm{Cl}^{-}$を IC 法で定量する方法を検討した。

$2 \cdot 3 \cdot 1$ の操作手順に従って ISE 用の分解キットで TCB 標準試料 $(2 \mathrm{mg} / \mathrm{kg})$ を分解し, 得られた分解抽出液をそ のまま IC 法で測定するとそのクロマトグラムはウォータ ーディップが大きく, $\mathrm{Cl}^{-}$を定量できない.これは，抽出 液が高濃度の水酸化ナトリウム溶液となり, 強アルカリ性 となるためである. 水の代わりに $0.5 \mathrm{~mol} / 1$ 硝酸液 $5 \mathrm{ml}$ で抽出して中和した結果, 中和液のクロマトグラムのウォ ーターディップが無くなり， $\mathrm{Cl}^{-}$を定量できるが，硝酸イ オンのピークが大きく, カラムを洗浄しても消失せず，引 き続く試料の分析にも影響する。そこで，抽出液中の $\mathrm{Na}^{+}$を吸着除去して抽出液を中性とし $\mathrm{Cl}^{-}$を定量するため に, 水素イオン型陽イオン交換樹脂を抽出液に加えて振り 混ぜる方法を検討した。 TCB 標準試料（TCB $3 \mathrm{mg} / \mathrm{kg}$ ) を使用した，樹脂の添加量と $\mathrm{Na}^{+}$の除去及び $\mathrm{Cl}^{-}$定量值の 関係を Fig. 2 に示す. 1 分解キット当たり樹脂を $1.5 \mathrm{~g}$ 以 上添加すれば $\mathrm{Na}^{+}$を除去できるが, $\mathrm{Cl}^{-}$濃度は $1.6 \sim 1.8$ $\mathrm{mg} / \mathrm{kg}$ となる。これは $\mathrm{PCB}$ 分解キットの空試験值 $(0.16$ 〜 $0.2 \mathrm{mg} / \mathrm{kgCl}^{-}$) も含んだ值である. L2000DX 分解キッ トの金属ナトリウム量は水を加えて中和滴定した結果，1 キット当たり $63.2 \mathrm{mg}$ であった。使用した水素イオン型陽 イオン交換樹脂の交換容量は $\geqq 1.5 \mathrm{mg}$ 当量 $/ \mathrm{ml}$ であり, ほぼ $1.8 \mathrm{ml}(\fallingdotseq 1.8 \mathrm{~g})$ の樹脂に対応する。これらの結果 から樹脂の添加量は $1.8 \mathrm{~g}$ とした. 


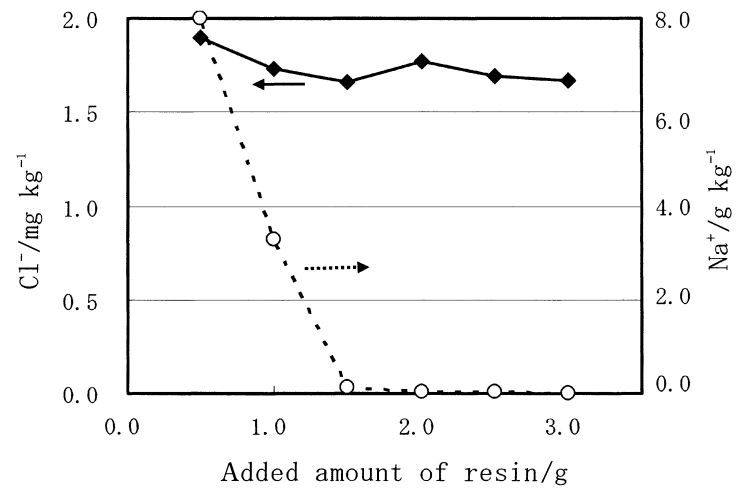

Fig. $2 \mathrm{Na}^{+}$removal and variation of $\mathrm{Cl}^{-}$in an extract vs. added amount of resin
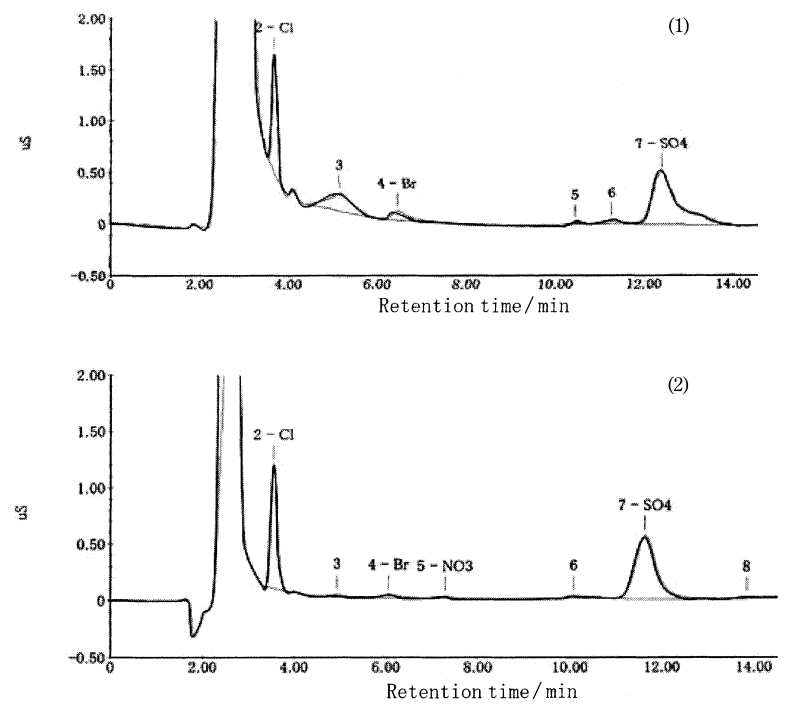

Fig. 3 Typical chromatogram of a sample

(1) Chromatogram of a sample decomposed using the original kit, (2) Chromatogram of a sample decomposed using the improved kit

分解キット自身に $\mathrm{Cl}^{-}$や有機塩素系化合物が含まれてい るとこれらは測定の誤差となる。このためキットの各部分 に含まれている $\mathrm{Cl}^{-}$を IC 法で測定した結果, L2000DX 用 の 1 キット当たりの $\mathrm{Cl}^{-}$は $0.8 \mu \mathrm{g}$ であることが分かった. これは $5 \mathrm{ml}$ の水に抽出した場合, $0.16 \mathrm{mg} / \mathrm{kg}$ となる.

PCB 分解キットを用いて試料を分解し水で抽出した液 を陽イオン交換樹脂で処理しイオンクロマトグラフで測定 するとクロマトグラムは Fig. 3（1）のようになり， $\mathrm{Cl}^{-}$の 前に大きなピークが現れ $\mathrm{Cl}^{-}$定量を妨害する。このピーク の成分は主として有機酸であり, 生成反応は試料の分解時 の溶媒及び金属ナトリウムの量に依存して起こることが予 想されたため, これらの試薬量と TCB の回収率への影響 を IC 法で調べた。試薬量を半量あるいは $1 / 4$ 量としても TCB の回収率は変わらなかった（Fig. 4). $\mathrm{Cl}^{-}$の前のピー

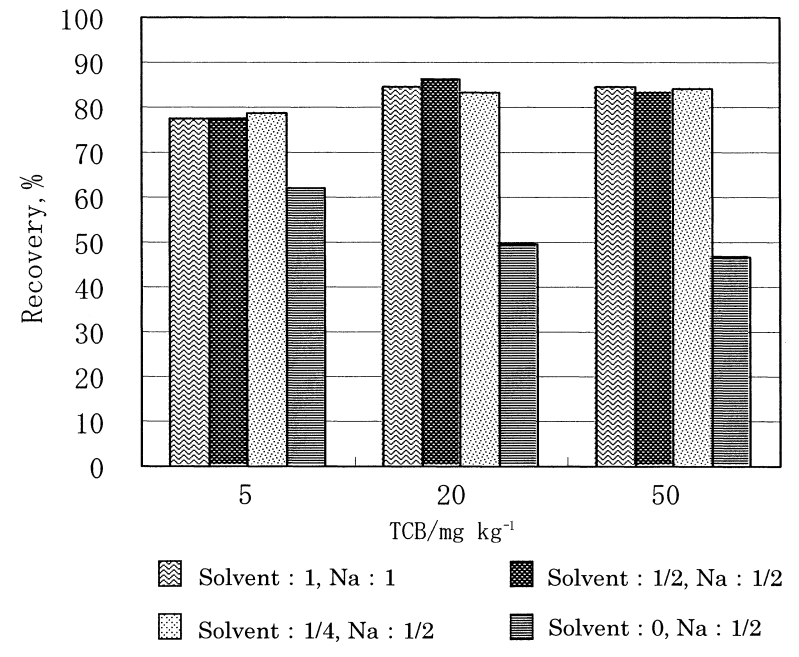

Fig. 4 Effect of solvent and metallic Na on TCB recovery

クを小さくするためには試薬量は少ないほど良いが，実試 料を分解する際, 多量の PCB を完全に分解するために試 薬量は半量とした。半量の試薬で絶縁油試料 $5 \mathrm{~g}$ 中 PCB として約 $2500 \mathrm{mg} / \mathrm{kg}$ を完全に分解できる. 試薬量を半減 したキットでは, $\mathrm{Cl}^{-}$の前のピークは小さくなり Fig. 3 (2) のようにクロマトグラムは改善された。そこでこれ以降, 試薬量は ISE 測定用の半量として実験を行った.

\section{$3 \cdot 2$ TCB での定量, 検量線と回収率}

$\mathrm{TCB}$ 標準液を改良キット（試薬量を半量化したキット） で 2・3・1の操作手順に従って分解し, IC 法で定量した結 果得られた検量線の直線性は TCB として0〜 $2 \mathrm{mg} / \mathrm{kg}$ で 十分であり，相関係数は 0.998 と良好であった。 TCB 中 の $\mathrm{Cl}^{-}$は $100 \%$ 回収されると $58.7 \%$ であるが，この検量 線の傾きは 0.492 であることから，回収率は $84 \%$ である ことが分かる. また, 測定可能な PCB の最大濃度は $3 \cdot 1$ で述べたように改良キットでは $2500 \mathrm{mg} / \mathrm{kg}$ の PCB まで 分解可能であり，この濃度である．IC 測定については高 濃度の場合, 抽出液を水で検量線の範囲まで希釈して測定 することで対応できる.

\section{$3 \cdot 3$ PCB での定量下限值}

$2 \cdot 2$ で述べた PCB の一種である KC600 の標準試料を用 いて定量下限值を算出するための実験を $2 \cdot 3 \cdot 2$ に従って 行った。相対標準偏差（RSD）10\% から求めた定量下限 值は $0.051 \mathrm{mg}(\mathrm{KC} 600) / \mathrm{kg}$ であった.これは $\mathrm{Cl}^{-}$に換算す ると $0.03 \mathrm{mg} / \mathrm{kg}$ に相当する.また KC300では 0.07 $\mathrm{mg} / \mathrm{kg}$ に相当するが，いずれにしてもこの結果は改良キ ットで絶縁油中の PCB を分解し, IC 法で定量する方法で 日本の卒業判定基準（PCB $0.5 \mathrm{mg} / \mathrm{kg}$ ）を十分に測定でき 


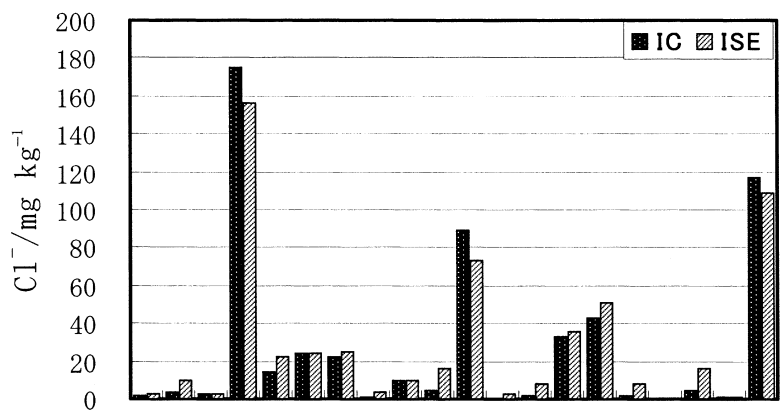

(1) (2) (3) (4) (5) (6) (7) (8) (9) (10) (11) (12) (13) (14) (15) (16) (17) (18) (19) (20) Sample No.

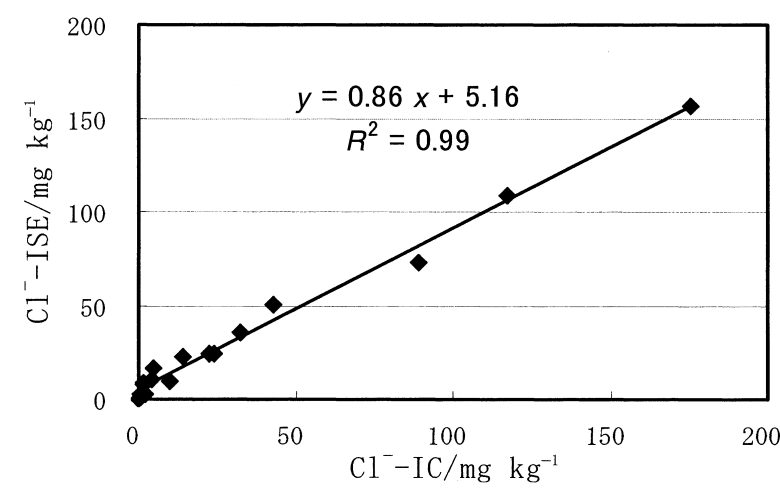

Fig. 5 Comparison of analytical results of PCB by IC method and ISE method

(1) Results of IC method and ISE method, (2) Correlation of IC method and ISE method

ることを示している.

\section{$3 \cdot 4$ 実試料の分析}

改良キットで $2 \cdot 2$ の実試料の分解と定量を $2 \cdot 3 \cdot 1$ の操 作手順に従い, 各試料について 3 回ずつ実施した。水で 抽出した後, 陽イオン交換樹脂 $1 \mathrm{~g}$ (試薬量を半量化した ため陽イオン交換樹脂量も半量とした）を添加し，分解キ ットを倒置して油分と抽出液を分離した。 実試料の場合, エマルジョンとなり分離せず，このままではIC 法による 分析はできないと判断される試料が見られた。そこで 3200 回転/分で 10 分間遠心分離を行ったところ, IC 法に よる定量が可能となった．この遠心分離は油分と抽出液の 分離が十分である試料には必要ないが，ここでは全試料を 同じ条件で分析するためにすべての試料について遠心分離 を行った. ISE 法の測定では通常のPCB の分解キット （米国デクシル製 L2000DX）を用いて，分解を行った後， キットに付属している硝酸塩溶液 $5 \mathrm{ml}$ を加えて 1 分間振 とう混和し $\mathrm{Cl}^{-}$を抽出した。 キットを 2 分間倒置して抽出 液と油分を分離させ，フィルターを通して抽出液のみを別 容器に取った。これを L2000DX 専用の塩化物イオン選択

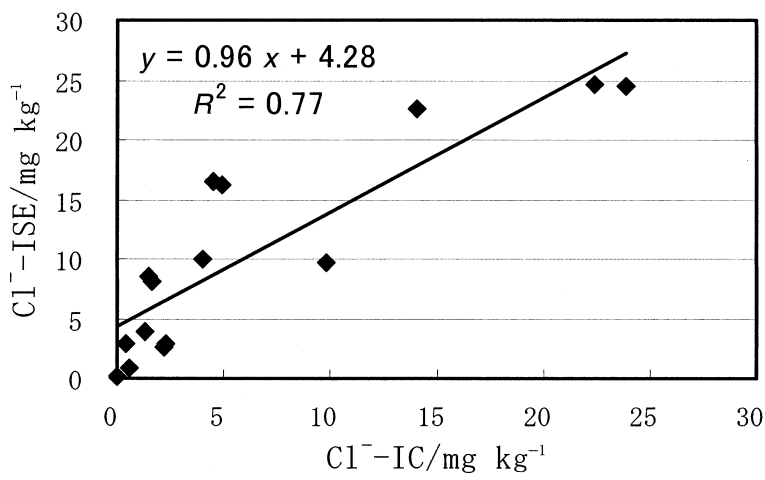

Fig. 6 Correlation of analytical results of PCB by IC method and ISE method in low concentration range

電極装置で測定した．実試料を IC 法と ISE 法で定量した 結果を Fig. 5 及び Fig. 6 に示す。これらの結果は得られ た測定值から空試験值を引いた值を回収率で補正して $\mathrm{Cl}^{-}$ 濃度として比較したものである。

Fig. 5 は全試料についての IC 法での結果と ISE 法の結 果を比較した。IC 法と ISE 法は良い相関関係が得られ， $\mathrm{Cl}^{-} 25 \mathrm{mg} / \mathrm{kg}$ 以上の濃度の試料では同等の結果が得られ た。また, $\mathrm{Cl}^{-}$として $25 \mathrm{mg} / \mathrm{kg}$ 以下の平均值を持つ試料 の結果を Fig. 6 に示す. 低濃度側ではかなりばらつきが 見られるが，試料(3)，(12)，(17)，(19)については低濃度であ っても IC 法と ISE 法の結果は良く一致している。これら の分解抽出液は透明で, 遠心分離の必要は無いと判断され た試料であった。これらの結果から $\mathrm{Cl}^{-} 0.5 \mathrm{mg} / \mathrm{kg}$ 以下の 実試料の分析も可能であることが分かる.

IC 法と ISE 法は両者共に同じ溶媒と金属ナトリウムに より PCBの分解を行うが，IC 法ではISE 法の半量の試薬 量で分解を行うという違いがある.ばらつきの見られた試 料(2)，(5)，(10，(13，16，18)についてはどちらの結果が正 しいかこれだけのデータからは判断できないが，ISE 法の 検出下限值が $5 \mathrm{mg} / \mathrm{kg}$ であることから $5 \mathrm{mg} / \mathrm{kg}$ 以下の PCB の測定值は信頼性に欠けると考えられる。あるいは， 試薬量の半量化が PCB の種類等の違いによる脱塩素化の 程度に何らかの影響を与えている可能性もある ${ }^{7 / 8)}$ と考え られる。

\section{4 結 語}

絶縁油中 PCB を分解し, 生成した塩化物イオンをイオ ンクロマトグラフ法で定量するための分解キットを改良し た. 水素イオン型陽イオン交換樹脂を添加し, 分解抽出液 を中性とした。また，分解キット中の金属 $\mathrm{Na}$ 量と分解溶 媒量を半量化し， $\mathrm{Cl}^{-}$の定量を妨害するピークを低減する ことにより精度良く $\mathrm{Cl}^{-}$を定量できるクロマトグラムが得 られた。これによる KC600の定量下限值は $0.051 \mathrm{mg} / \mathrm{kg}$ 
であった。ISE 法と IC 法での実試料の分析結果は 5 $\mathrm{mg} / \mathrm{kg}$ 以下ではばらつきも見られたが，全体的には良く 一致していた。改良された $\mathrm{PCB}$ 分解キットで絶縁油中の 低濃度 PCB の存在をスクリーニングできることが明らか になった．改良キットの製品化に当たっては陽イオン交換 樹脂を分解試薬と同様にガラス管に封入し，キットの中で 割って使用できるようにする予定である。これにより操作 性の向上とコンタミの除去を期待できる.

$$
\left(\begin{array}{l}
2004 \text { 年 } 9 \text { 月, 日本分析化学会 } \\
\text { 第 } 53 \text { 年会及び } 2004 \text { 年 } 12 \text { 月, } \\
\text { 日中韓合同イオンクロマトグラ } \\
\text { フィー討論会において一部発表 }
\end{array}\right)
$$

\section{文献}

1) 2001 年 8 月 1 日 JEMA (日本電機工業会) 環境部編: “PCB 問題をめぐる動向について”.

2) JIS K 0093, 用水・排水中のポリクロロビフェニル (PCB) の試験方法 (2002).

3) デクシル社 L200DX 取扱説明書.

4) N. D. Scott, J. F. Walker, V. L. Hansley: J. Am. Chem. Soc., 58, 2442 (1936).

5) Fieser \& Fieser: Reagents for Organic Synthesis, 1, p. 711 (1967), (J. Wiley \& Sons, New York).

6) L. M. Liggett: Anal. Chem., 26, 748 (1954).

7) 有泉 彰, 大塚哲郎，神山昌士，細見正明：環境化 学, 7, 793 (1997).

8) 野馬幸夫，酒井伸一，光原好人，松山喜代志：第 15 回廃棄物学会研究発表会講演論文集 2004, E1-2, 1310 (2004).

\section{要旨}

塩化物イオン選択性電極（ISE 法）を用いて絶縁油中のポリ塩化ビフェニル（PCB）を測定する市販の PCB 分解キットを, イオンクロマトグラフ (IC) 法で $0.5 \mathrm{mg} / \mathrm{kg}$ 以下の PCB を定量できるように改良した. これは日本で新たに設定された絶縁油中の PCB 廃裹基準值が $0.5 \mathrm{mg} / \mathrm{kg}$ であるのに対して, ISE 法を使用 している従来のキットでは定量下限值は $5 \mathrm{mg} / \mathrm{kg}$ であり，これに対応できないためである. PCB 分解キッ 卜の基本的な操作手順は以下の通りである; PCB を含む絶縁油のサンプルをキットの中で安定化した金属 $\mathrm{Na}$ と溶媒によって PCB を塩化物イオンに分解する。この塩化物イオンを水で抽出し, IC 法で定量し, PCB の值に換算する。この方法では, 分解後の抽出液が生成物の $\mathrm{NaOH}$ により強アルカリとなり, ウォー ターディップが大きいため，精度良く塩化物イオンを定量することができない。これは PCB の分解剤とし て多量の金属 $\mathrm{Na}$ を用いているために起こる．抽出液中の多量の $\mathrm{Na}^{+}$を除去し中性にするために，陽イオン 交換樹脂を使用すること，また分解剤の $\mathrm{Na}$ と溶媒の量を従来のキットの半量とすることで良好な塩化物イ オンのクロマトグラムを得たＩC 法と ISE 法による実試料の分析結果は比較的良く一致していたが，PCB 含有量 $5 \mathrm{mg} / \mathrm{kg}$ 以下ではばらつきが見られた。この新しい方法は絶縁油中の PCB 廃棄基準值の $0.5 \mathrm{mg} / \mathrm{kg}$ のスクリーニングに有効であることが分かった。 